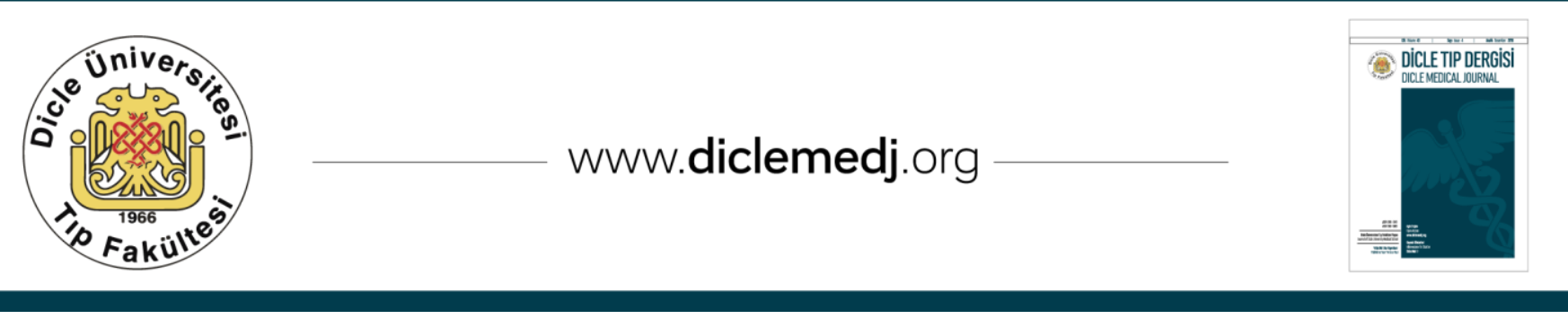

Original Article / Özgün Araştırma

\title{
Quality of Life and Self-Efficacy of Adolescents with Chronic Health Conditions
}

\author{
Demet Taş¹, Ebru Öztürk Çopur², Hande Ünlü³ , Zeynep Tüzün, Lütfiye Hilal Özcebe \\ 1 Ankara Dişkapi Çocuk Sağlı̆̆ ve Hastalıkları Hematoloji Onkoloji Eğitim ve Araștırma Hastanesi, Ankara, Turkey ORCID: 0000-0003-2586-5740 \\ 2 Department of Public Health, Hacettepe University Faculty of Nursing, Ankara, Turkey \\ 3 Institute of Public Health, Hacettepe University, Ankara, Turkey \\ 4 Department of Adolescent Health, Children's Health Institute, Hacettepe University Faculty of Medicine, Ankara, Turkey
}

Received: 27.04.2017; Revised: 27.06.2017; Accepted: 27.07.2017

\begin{abstract}
Objective: Chronic Health Conditions (CHC) and problems among adolescents have recently become more frequent. CHC may have an influence on their perception of quality of life and self-efficacy. This research aimed to compare quality of life and self-efficacy among adolescents with CHC and without CHC.

Methods: The research was conducted with 778 adolescents from a high school. Students were asked as follows: "Have you had any health condition which requires a doctor supervision and/or which requires continuous medication (pills, injection, oral or nasal usage) at least for 6 months or more?" All students completed the SelfEfficacy Questionnaire for Children (SEQ-C) and Pediatric Quality of Life Inventory (PedsQL).

Results: All diseases declared by the students are accepted as chronic health conditions. The frequency of having chronical health condition is $19.5 \%$ among the high school students. PedsQL for adolescents with CHC were significantly lower compared to those without CHC $(\mathrm{p}<0.001)$. When sub-groups of PedsQL were examined, it was found that adolescents with $\mathrm{CHC}$ had significantly lower school functioning scores compared to other subscale scores $(p=0.005)$. There was no statistically significant difference between the participants with CHC and others in terms of (SEQ-C) $(\mathrm{p}>0.05)$.

Conclusion: It has been observed that the PedQL of students with chronic health problems was negatively affected as a result of our work. Lower QoL associated with school functioning of adolescents with chronic health problems suggests the importance of school-related factors (friends, teachers and physical structure) in the intervention of improving quality of life.
\end{abstract}

Keywords: Chronic health conditions, adolescent, self-efficacy, quality of life

DOI: $10.5798 /$ dicletip.339004

Yazışma Adresi / Correspondence: Demet Taş, Ankara Dışkapı Çocuk Sağlığı ve Hastalıkları Hematoloji Onkoloji Eğitim ve Araştırma Hastanesi, Ankara, Turkey e-mail: demettas19691@hotmail.com 


\section{Kronik Sağlık Sorunu Bulunan Ergenlerin Yaşam Kalitesi ve Öz-Yeterliliği}

\section{Özet}

Amaç: Son yıllarda ergenlerde kronik sağlık sorunu sıklığının arttığı tespit edilmiştir. Ergenlerin bu durum ile başa çıkmaya çalışırken yaşam memnuniyetinin de etkileneceği düşünülmüştür. Çalışmamızda kronik sağlık sorunu olan ve olmayan ergenlerin yaşam kalitesi ve öz-yeterlilik durumlarının karşılaştırılması amaçlanmıştır.

Yöntemler: Araştırma 778 kişinin katıldığı lise öğrencileri ile yapılmıştır. Öğrencilere demografik sorularla birlikte "Son 6 ay, ya da daha uzun süre doktor takibinde olmanızı gerektiren ve/veya devamlı ilaç (hap, iğne, ağızdan veya burundan hava uygulaması gibi) kullanmanızı gerektiren bir sağlık sorununuz var mı? ( varsa lütfen hastalığın adını yazınız)" sorusu yöneltilmiştir. Bu soruya birden fazla cevap verebilecekleri belirtilmiştir. Sorunun devamında "Pediyatrik Yaşam Kalitesi Ölçeği” ve "Çocuklar İçin Öz-Yeterlilik Ölçeği”ni doldurmaları istenmiştir.

Bulgular: Öğrenciler tarafından belirtilen tüm hastalıklar kronik sağlık sorunu olarak kabul edilmiştir. Çalışmada verilen cevaplar doğrultusunda öğrencilerin \%19,5'inde kronik sağlık sorunu tespit edilmiştir ve yaş ortalaması $16,44 \pm 1,10$ bulunmuştur. Kronik sağllk sorunu bulunmayan ergenlerin yaş ortalaması ise $16,22 \pm 1,10$ 'dir. Kronik sağlık sorunu bulunanlarda toplam yaşam kalitesi $(p<0.001)$ ve okul işlevsellik yaşam kalitesi puanları $(p=0.005)$, istatistiksel olarak anlamlı düşük bulunmuştur. Kronik sağlık sorunu olan ve olmayan ergenlerin öz-yeterlilik ve alt grup puanları arasında anlamlı bir farklılık görülmemiştir ( $\mathrm{p}>0.05)$.

Sonuç: Çalışmamızın sonucunda kronik sağlık sorunu olan ergenlerin yaşam kalitesinin olumsuz etkilendiği görülmüştür. Kronik sağlık sorunu bulunan ergenlerin, okul işlevselliği ile ilgili yaşam kalitesinin düşük olması ise yaşam kalitesinin iyileştirilmesi müdahalesinde okul ile ilişkili faktörlerin (arkadaş, öğretmen ve fiziki yapı) önemini ortaya koymuştur.

Anahtar kelimeler: Kronik sağlık sorunu, yaşam kalitesi, öz-yeterlilik, ergen

\section{INTRODUCTION}

CHC in adolescents have become more frequent, since the end of 20th century ${ }^{1}$. The prevalence of CHC in Sweden for adolescents aged to 14-18 years old has increased from $8.6 \%$ to $16.4 \%$ during the last 20 years. It is believed that the reason for this increase may be better medical care of childhood conditions and increase in recollection of behavioral, developmental, and sentimental conditions during both childhood and adolescence ${ }^{2}$. The biological, physical, and psycho-social changes in adolescents may affect the course of $\mathrm{CHC}$, as CHC could influence puberty development occurred in this period. Adolescence is a period of rapid changes of both physical and psychological. That's why adolescents with CHC may have an additional burden. This situation may adversely affect their social life as well as their physical life like relations with friends, scholastic achievements, and school life ${ }^{3,4}$.
Quality of life (QoL) is defined as how an individual perceives life in terms of thought, life standard and purpose depending on his/her culture and values ${ }^{5}$. QoL is a multi-factor concept that explains how an individual perceives his/her physical, psychological and social condition ${ }^{6}$. The way one perceives his/her QoL depends especially on which phase of life he/she is in. In some studies, it is mentioned that the data provided by adolescents regarding their QoL is reliable and better results can be achieved if other additional scales are used ${ }^{7}$. Perception of QoL in adolescents can be different from that of adults due to their perception of events in the pubertal development period ${ }^{8}$. The perception of QoL in adolescents is based on how their health problems affect their plans for the future and their ambitions. In this framework, scales which are proper for their age should be developed and applied 4 . 
Self-efficacy (SEQ) which is commonly used to determine the applicability of self-management with regard to $\mathrm{CHC}$, is one of the concepts of "Social-Cognitive Theory". Self-efficacy is the perception of an individual's own capacity to carry out and organize necessary activities to overcome difficulties he/she faces. The perception level of self-efficacy can be determinant for one's motivation and success when faced with difficulties such as diseases. The higher one's self-efficacy levels are, the better their ability to think positive and overcome the difficulties can be ${ }^{9,10}$. Adolescents feel much better when they accept the disease easily and adapt to it. Young person, who accepts his/her disease and its treatment options, adapts to daily life better and also sets goals. Thus he/she feels self-sufficient ${ }^{11}$.

It is known that the QoL of adolescents with CHC are usually adversely affected. However, community-based QoL and self-efficacy status of adolescents with CHC have not been studied in Turkey before. Our study is basically based on the hypothesis which accepts that QoL and Self-efficacy among adolescents with CHC are lower than the healthy adolescents.

\section{METHODS}

The study was conducted in a high school located in the center of the Ankara province. The high school preparatory class, 9th and 10th grade students were invited in the study. Consequently, 778 out of total 887 students $(87.7 \%)$ who had consents from their parents and were volunteers to give their own consent were included in the study.

One week before collecting the data, all the preparatory class, 9th and 10th grade students were visited and given the consent forms and information about the study. The consent forms were gathered by the teachers and delivered to the researchers. The questionnaires were collected from the participants who were ready at the school and have both parental and personal consent forms.
The students completed demographic questionnaire (birth date, sex, grade). The students were also asked parents' level of education (either 8th grade or less /high school or more) and their family income level (low/medium/high) to determine their Socio Economic Status (SES). In order to figure out whether their parents have CHC, the students were asked whether their parents use health services frequently and/or receive medication continuously.

The following comprehensive questions were asked to detect whether there was a chronic health condition in participants: "Have you had any health condition (asthma, allergy, constant upper and/or lower respiratory ailment, diabetes, kidney and/or urinary tract disorders, cardiac problems, blood diseases, attention deficit and/or hyperactivity, hematologic diseases, gastrointestinal diseases, physical disability, rheumatic diseases, obesity) which requires a doctor supervision and/or which requires continuous medication (pills, injection, oral or nasal usage) (If, yes please provide its name) at least for 6 months or more?" The participants were explained that it was possible to write more than one health condition. All diseases declared by the students are accepted as chronic health conditions. All students completed the Self-Efficacy Questionnaire for Children (SEQ-C) and Pediatric Quality of Life Inventory (PedsQL).

\section{Human Subjects Approval Statement}

Hacettepe University Non-interventional Clinical Researches Ethics Board had approved the study before it was conducted.

\section{Self-Efficacy Questionnaire for Children (SEQ-C)}

Self-efficacy Questionnaire for Children (SEQ-C) was developed by Muris ${ }^{12}$ in order to evaluate social, academic and emotional self-efficacy of adolescents who were 12 -19 years old. The scale was adapted to Turkish adolescents by Telef ${ }^{13}$. Internal consistency coefficients of SEQ- 
$\mathrm{C}$ are examined, and Cronbach's alpha $(\alpha)$ value for overall scale is found $\alpha=0.86$, test-retest reliability of the scale varies between 0.75 and 0.89, which secures reliability between "acceptable" and "good". SEQ-C is a five-item Likert type ( $1=$ none and $5=$ very good) scale. The maximum score at the end of the scale is 105 , while the minimum value of 21 . High scores mean that the adolescent has a high level of self-efficacy while low scores mean the opposite.

\section{Pediatric Quality of Life Inventory (PedsQL)}

For the evaluation of life quality, PedsQL was used for those students who were 13-18 years old. PedsQL for Children is a general QoL scale which was developed by Varni et al. to evaluate physical and psycho-social life of children who were 13-18 years old, regardless of their diseases ${ }^{14}$. The validity and reliability for Turkish version of PedsQL for Children for 8-12 and 13-18 age groups was tested by Çakın Memik et al.15. The internal consistency (Cronbach's alpha) of the scale was found $\alpha=0.82$ for the child self-report and $\alpha=0.87$ for the parent proxy report. In this scale, there are four sub-sections which focus on physical, emotional, social, and school functioning of children. A five-item Likert type scale is also used in this scale ( $0=$ never and $4=$ always). While the scores get higher within the range of 0 and 100, the QoL increases.

\section{Data Analysis}

A database was created through SPSS program upon information collected by questionnaire and scales. Then, it had been transferred to digital format. Numeric variables were provided as Mean (M) \pm Samples Standard Deviation (SD) while categorical variables were given as percentages. The goodness of fit test of numeric variables to normal distribution was determined using Shapiro-Wilk Test (small sample size) and Kolmogorov-Smirnov Test (large sample size). Equality of variance of numeric variables was tested by using Levene Test. Independent Sample t-test was used to assess the difference in means between two independent samples when normality assumption was satisfied, while Mann-Whitney $\mathrm{U}$ Test was used to compare two independent samples when normality assumption was not satisfied. Pearson chi-square test was used to evaluate the categorical variables. Significance level 0.05 was used and it was accepted as significantly different when $\mathrm{p}<0.05$.

\section{RESULTS}

Total 778 students who participated in the study were at the average age of $16.3 \pm 1.1$ and were comprised of $55.3 \%(n=431)$ female and $44.7 \%(n=347)$ male students. $19.5 \%(n=152)$ of the participants had CHC.

Diseases that were stated as CHC were as follows: Asthma $(n=43)$, iron deficiency anemia $(\mathrm{n}=28)$, skin problems $(\mathrm{n}=15)$, cardiac diseases $(n=13)$, diabetes $(n=10)$, kidney and urinary tract disorders $(n=10)$, psychological disorders $(n=9)$, epilepsy $(n=8)$, obesity $(n=7)$, gastrointestinal diseases $(n=6)$, rheumatic diseases $(n=4)$, migraine $(n=4)$, physical disability $(n=3)$, meniscal tear $(n=1)$, faintness $(n=1)$ and dental problems $(n=1)$. Distribution of CHC statements by high school students based on their and their families' sociodemographic characteristics will be seen in Table1.

Total PedsQL and school functioning sub-scale were found significantly lower among students who reported their $\mathrm{CHC}$ compared to those who did not have any CHC. When total SEQ-C and its sub-scale scores were evaluated, no significant difference was found between individuals with $\mathrm{CHC}$ and without CHC. (Table 2). 
Table I. Distribution of CHC statements by high school students based on their and their families' sociodemographic characteristics

\begin{tabular}{|c|c|c|c|c|}
\hline \multirow{3}{*}{$\begin{array}{l}\text { Demographic } \\
\text { characteristics }\end{array}$} & \multicolumn{2}{|c|}{ Chronic Health Condition } & \multirow[b]{2}{*}{ Total } & \multirow{3}{*}{$\mathbf{p}$} \\
\hline & Yes & No & & \\
\hline & n (\%) & n (\%) & n (\%) & \\
\hline \multicolumn{5}{|l|}{ Gender } \\
\hline Male & $57(16.4)$ & $290(83.6)$ & $347(44.6)$ & \multirow{3}{*}{0.05} \\
\hline Female & $95(22.0)$ & $336(78.0)$ & $431(55.4)$ & \\
\hline Total & $152(19.5)$ & $626(80.5)$ & $77(100.0)$ & \\
\hline \multicolumn{5}{|l|}{ Grade } \\
\hline Preparatory & $40(15.2)$ & $223(84.8)$ & $263(33.8)$ & \multirow{4}{*}{0.015} \\
\hline $9^{\text {th }}$ & $36(17.6)$ & $168(82.4)$ & $204(26.2)$ & \\
\hline $10^{\text {th }}$ & $76(24.4)$ & $235(75.6)$ & $311(40.0)$ & \\
\hline Total & $152(19.5)$ & $626(80.5)$ & $778(100.0)$ & \\
\hline \multicolumn{5}{|c|}{ Mother's level of education } \\
\hline 8 years and less & $24(16.9)$ & $118(83.1)$ & $142(18.3)$ & \multirow{3}{*}{0.381} \\
\hline High school and more & $128(20.1)$ & $508(79.9)$ & $636(81.7)$ & \\
\hline Total & $152(19.5)$ & $626(80.5)$ & $778(100.0)$ & \\
\hline \multicolumn{5}{|c|}{ Father's level of education } \\
\hline 8 years and less & $6(9.0)$ & $61(91.0)$ & $67(8.6)$ & \multirow{3}{*}{0.022} \\
\hline High school and more & $146(20.5)$ & $565(79.5)$ & $711(91.4)$ & \\
\hline Total & $152(19.5)$ & $626(80.5)$ & $778(100.0)$ & \\
\hline \multicolumn{5}{|c|}{ Perception of SES of the family } \\
\hline Low and very low ES & $4(28.6)$ & $10(71.4)$ & $14(1.8)$ & \multirow{4}{*}{0.575} \\
\hline Middle ES & $52(18.2)$ & $233(81.8)$ & $285(36.6)$ & \\
\hline High ES & $96(20.0)$ & $383(80.0)$ & $479(61.6)$ & \\
\hline Total & $152(19.5)$ & $626(80.5)$ & $778(100.0)$ & \\
\hline \multicolumn{5}{|l|}{${ }^{*} \mathrm{CHC}$ of the mother } \\
\hline Yes & $67(31.3)$ & $147(68.7)$ & $214(27.5)$ & \multirow{3}{*}{$<0.001$} \\
\hline No & $85(15.1)$ & $479(84.9)$ & $564(72.5)$ & \\
\hline Total & $152(19.5)$ & $626(80.5)$ & $778(100.0)$ & \\
\hline \multicolumn{5}{|l|}{${ }^{*}$ CHC of the father } \\
\hline Yes & $45(29.6)$ & $107(70.4)$ & $152(19.5)$ & \multirow{3}{*}{$<0.001$} \\
\hline No & $107(17.1)$ & $519(82.9)$ & $626(80.5)$ & \\
\hline Total & $152(19.5)$ & $626(80.5)$ & $778(100.0)$ & \\
\hline Age average & $16.44 \pm 1.10$ & $16.22 \pm 1.10$ & $778(100.0)$ & 0.024 \\
\hline
\end{tabular}

* Chronic Health Condition 
Taş D., Çopur E.Ö., Ünlü H., Tüzün Z., Özcebe L.H.

Table II. PedsQL and SEQ-C scores based on the statement of CHC

\begin{tabular}{lccc}
\hline & \multicolumn{2}{c}{ Chronic Health Condition } & p \\
\cline { 2 - 3 } & Yes (n=152) & No (n=626) & Mean \pm SD \\
\hline *PedsQL subscale scores & & & \\
\hline & & & \\
Physical functionality & $24.07 \pm 5.72$ & $25.04 \pm 4.74$ & 0.157 \\
Emotional functionality & $12.89 \pm 3.59$ & $13.50 \pm 3.47$ & 0.059 \\
Social functionality & $17.22 \pm 3.31$ & $17.42 \pm 3.21$ & 0.483 \\
School functionality & $11.76 \pm 3.90$ & $13.36 \pm 3.46$ & $<\mathbf{0 . 0 0 1}$ \\
Total Scale Score & $65.94 \pm 12.36$ & $69.33 \pm 11.11$ & $\mathbf{0 . 0 0 5}$ \\
**SEQ-C subscale scores & & & \\
Academic self-efficacy & $20.94 \pm 5.50$ & $21.51 \pm 5.33$ & 0.235 \\
Social self-efficacy & $25.31 \pm 4.47$ & $25.00 \pm 4.69$ & 0.518 \\
Emotional self-efficacy & $21.02 \pm 5.92$ & $21.85 \pm 5.38$ & 0.114 \\
Total Scale Score & $67.27 \pm 12.05$ & $68.37 \pm 11.53$ & 0.132 \\
\hline
\end{tabular}

*Pediatric Quality of Life Inventory

** Self-Efficacy Questionnaire for Children

$\underline{\text { Table III. PedsQL scale scores based on the statement of CHC by male and female students }}$

\begin{tabular}{|c|c|c|c|}
\hline \multirow{3}{*}{ *PedsQL sub-scale scores } & \multicolumn{2}{|c|}{ Chronic Health Condition } & \multirow{3}{*}{$\mathbf{p}$} \\
\hline & Yes & No & \\
\hline & Mean \pm SD & Mean \pm SD & \\
\hline Male & $n=57$ & $n=290$ & \\
\hline Physical functionality & $25.26 \pm 5.32$ & $26.28 \pm 4.53$ & 0.157 \\
\hline Emotional functionality & $13.16 \pm 3.86$ & $14.14 \pm 3.57$ & 0.059 \\
\hline Social functionality & $16.68 \pm 4.21$ & $17.26 \pm 3.41$ & 0.483 \\
\hline School functionality & $12.12 \pm 3.75$ & $13.37 \pm 3.77$ & $<0.001$ \\
\hline Total Scale Score & $67.23 \pm 12.98$ & $71.04 \pm 11.43$ & 0.005 \\
\hline Female & $n=95$ & $n=336$ & $\mathbf{p}$ \\
\hline Physical functionality & $23.35 \pm 5.86$ & $23.97 \pm 4.66$ & 0.651 \\
\hline Emotional functionality & $12.74 \pm 3.43$ & $12.95 \pm 3.29$ & 0.632 \\
\hline Social functionality & $17.55 \pm 2.60$ & $17.56 \pm 3.02$ & 0.634 \\
\hline School functionality & $11.54 \pm 3.99$ & $13.36 \pm 3.17$ & $<0.001$ \\
\hline Total Scale Score & $65.17 \pm 11.97$ & $67.84 \pm 10.62$ & 0.083 \\
\hline
\end{tabular}

* Pediatric Quality of Life Inventory 
Total PedsQL Scale was found significantly low among those male students with CHC compared to those without CHC. Female and male students with $\mathrm{CHC}$ have significantly lower school functioning sub-scale scores.(Table 3).

Adolescents whose parents had high school or higher education, total PedsQL score, emotional, and school functionality subs-cale scores

of those with $\mathrm{CHC}$ were found significantly lower than those without CHC $(\mathrm{p}<0.05)$.

Adolescents whose families had high SES total PedsQL score and its emotional and school functioning sub-scale scores of those with CHC were found to be significantly lower than those without CHC $(\mathrm{p}<0.05)$.

There was no statistically significant difference between total Self-Efficacy and their sub-scale scores in terms of the socio-demographic characteristics of participants with and without CHC ( $p>0.05)$.

\section{DISCUSSION}

In this study, both $\mathrm{CHC}$ related quality of life and self-efficacy in adolescents were studied for the first time in Turkey. All diseases declared by the students are accepted as chronic health condition. The adolescent's declaration of having $\mathrm{CHC}$ is found as $19.5 \%$. Almost 1 out of 6 adolescent stated as having CHC. Denny et all also defined CHC as a chronic health problem which lasts at least 6 months in their study in New Zealand, the percentage of CHC was found as \%18, which is similar to our finding ${ }^{16}$.

We found that total PedsQL was lower among adolescents with CHC than those without CHC, as expected. Unlike this result, SEQ-C in both groups was similar. The perception of QoL which depends on adolescent's health problems has gained much more importance due to the negative circumstances such as disease follow-ups, possible physical changes, school absenteeism and academic failure. Lee et al. reported that children and adolescents with CHC have lower QoL 7 . Denny et all also showed in their study that $\mathrm{CHC}$ of adolescents had negative impact on them ${ }^{16}$.

In our study, total PedsQL in male students with CHC was found significantly low compared to those without CHC while it is not low among female students. Erturan et all showed that adolescents with atopic dermatitis have lower QoL and that QoL in female adolescents is lower than QoL in males ${ }^{17}$. Studies show that patients with juvenile idiopathic arthritis and acne vulgaris have low QoL due to the disease regardless of gender ${ }^{18,19}$ Waters et all stated that QoL of adolescents with $\mathrm{CHC}$ was low, while there was also gender difference depending on the disease ${ }^{7}$.

When sub-scales of PedsQL were evaluated, the school functionality sub-scales score of CHC students were found significantly lower than healthy adolescents for both genders. In their research, Durualp et al. found the total QoL and physical health, social and school functionality sub-scales scores low among 14-18 years old adolescents with $\mathrm{CHC}^{20}$. It was also observed that adolescents did not feel good at school when they were among their healthy friends depending on the mid-puberty when peer influence and independency impulse were very strong ${ }^{21}$. Using medications at school, school absenteeism, doctor follow-ups, the disease itself, and academic failure anxiety were thought to be effective in the low school functionality scores. The severity of the disease is not the only usual reason that influences adversely the school functionality of adolescents with $\mathrm{CHC}$, the state of having the disease can also negatively affect the adolescents' psychology and impair school functionality as well ${ }^{3}$.

Zashikhina et al. reported that even if full cost of treatment was covered, high-income impacted QoL in a positive way. Furthermore, children of parents with higher education 
might have a higher QoL. It was expressed that this type of parents was more conscious and they can inform their children better ${ }^{22}$. In studies conducted among asthma patients, a parallel link was found between the parents' level of income and adolescents' perception of QoL ${ }^{23}$. Our finding is not similar to other studies. In our study, in families with high economic situation and well educated parents, total QoL scores and school functionality subscale scores of participants with chronic health condition were found to be significantly low. Most of the parents in our study were high school or university graduates. Parents' higher level of education and higher rate of academic success at the school revealed that these parents had paid much more attention to the health and academic condition of their children. It was also thought that parents with higher level of education and better economic situation might be more concerned for their children's future in terms of health and scholastic achievement, and they might have reflected this concern to their children. We found a statistically significant positive correlation between parents' having CHC. This was an expected result due to familial predisposition of $\mathrm{CHC}^{24}$.

SEQ -C is seen as one of the criteria to cope with positive and negative situations, providing state of well-being, positive thinking and the management of academic and social conditions ${ }^{25-27}$. In two studies conducted in different times, SEQ-C and self-respect were low for adolescents diagnosed with DM Type 1 and who didn't show any compliance with the disease. It was stated that efforts to increase self-respect and SEQ-C might also increase the level of compliance with the disease and treatment and would bring success ${ }^{28,29}$. In our study, perception of SEQ-C of students with CHC was found similar to healthy students. It was accepted that the adolescents with $\mathrm{CHC}$ are able to cope with their health problems.
As the result of our study, the total PedQL and school functionality sub-scales score of CHC students were found significantly lower than healthy adolescents. Lower QoL associated with school functioning of adolescents with chronic health problems suggests the importance of school-related factors (friends, teachers and physical structure) in the intervention of improving quality of life.

\section{Limitations}

The study group was not homogenous because it was conducted in only one school for which the conditions of admission were based on an examination. The definition of CHC is explained in materials and methods, the group is composed of the declaration of the students. Students may have concealed their health condition or we may have collected misleading data about the disease, since we directly posed questions to students by giving them the definition of CHC. Students who were volunteers to participate in and ready at the school on the date of the study were included in the study. Therefore, those who were registered to the school but were not able to attend the school because of a physical or mental disability or a severe disease or who had to be under the supervision of a doctor were not included in the study. The research was not conducted with enough number of students having a specific disease to allow us to evaluate the effect of these diseases on QoL scores individually.

Declaration of Conflicting Interests: The authors declare that they have no conflict of interest.

Financial Disclosure: No financial support was received 


\section{REFERENCES}

1. Maslow GR, Chung RJ. Systematic review of positive youth development programs for adolescents with chronic illness. Pediatrics 2013;131:1605-18.

2. Berntsson L, Berg M, Brydolf M, Hellström A-L. Adolescents' experiences of well-being when living with a long-term illness or disability. Scand J Caring Sci. 2007;21:419-25.

3. Suris JC, Michaud PA, Viner R. The adolescent with a chronic condition. Part I: developmental issues. Arch Dis Child. 2004;89:938-42.

4. Taylor RM, Gibson F, Franck LS. A concept analysis of health-related quality of life in young people with chronic illness. J Clin Nurs. 2008;17:1823-33.

5. Eiser C, Morse R. A review of measures of quality of life for children with chronic illness. J Clin Nurs. 2001; 84:205-11.

6. Sawyer MG, Reynolds KE, Couper JJ, et al. Healthrelated quality of life of children and adolescents with chronic illness-a two year prospective study. Qual Life Res .2004; 13:1309-19.

7. Waters EB, Salmon LA, Wake M, et al. The health and well-being of adolescents: a school-based population study of the self-report Child Health Questionnaire. J Adolesc Health. 2001;29:140-9.

8. Huebner ES, Valois RF, Suldo SM, et al. Perceived quality of life: a neglected component of adolescent health assessment and intervention. T J Adolesc Healt. 2004; 34:270-8.

9. Bandura A. Social cognitive theory: an agentic perspective. Annu Rev Psychol. 2001;52:1-26.

10. Modi AC, Pai AL, Hommel KA, et al. Pediatric selfmanagement: a framework for research, practice, and policy. Pediatrics 2012;129:e473-e85.

11. Casier A, Goubert L, Gebhardt WA, et al. Acceptance, well-being and goals in adolescents with chronic illness: A daily process analysis. Psychol Health. 2013;28:1337-51.

12. Muris P. A brief questionnaire for measuring selfefficacy in youths. J Psychopathol Behav Assess.2001; 23:145-9.

13. Telef, B.B., Karaca, R. (2011). Ergenlerin ÖzYeterliklerinin ve Psikolojik Semptomlarının İncelenmesi. Mustafa Kemal Üniversitesi Sosyal Bilimler Enstitüsü Dergisi. 16:499-18.

14. Varni JW, Seid M, Rode CA. The PedsQL: measurement model for the pediatric quality of life inventory. Medical Care 1999; 37:126-39.

15. Memik NC, Ağaoğlu B, Coşkun A, ve ark. Çocuklar için yaşam kalitesi ölçeğinin 13-18 yaş ergen formunun geçerlik ve güvenilirliği. Türk Psikiyatri Dergisi 2007; 18:353-63.

16. Denny S, de Silva M, Fleming T, et al. The prevalence of chronic health conditions impacting on daily functioning and the association with emotional well- being among a national sample of high school students. J Adolesc Health. 2014; 54:410-5.

17. Erturan İ, Aktepe E, Balcı DD, et al. Atopik dermatitli ergenlerde benlik saygısı ve dermatolojik yaşam kalitesinin değerlendirilmesi. Türkderm. 2013; 47:3944.

18. Shaw KL, Southwood TR, Duffy CM, McDonagh JE. Health-related quality of life in adolescents with juvenile idiopathic arthritis. Arthritis And Rheumatism. 2006; 55:199-207.

19. Akyazı H, Baltacı D, Alpay K, Hocaoğlu Ç. Quality of life in adult patients with acne vulgaris before and after treatment. Dicle Medical Journal/Dicle Tıp Dergisi 2011; 38:282-8.

20. Durualp E, Kara FN, Yilmaz V, AlabeyoĞLu K. Kronik hastalı̆̆ı olan ve olmayan çocukların ve ebeveynlerinin görüşlerine göre yaşam kalitelerinin karşılaştırılması. Ankara Üniversitesi Tıp Fakültesi Mecmuası 2010; 63:055-63.

21. Ladd GW. Peer relationships and social competence during early and middle childhood. Annu Rev Psychol. 1999; 50:333.

22. Zashikhina A, Hagglof B. Health-related quality of life in adolescents with chronic physical illness in northern Russia: a cross-sectional study. Health Qual Life Outcomes 2014; 12:12.

23. Erickson SR, Munzenberger PJ, Plante MJ, et al. Influence of sociodemographics on the health-related quality of life of pediatric patients with asthma and their caregivers. J Asthma. 2002; 39:107-17.

24. Yoon PW, Scheuner MT, Jorgensen C, Khoury MJ. Developing Family Healthware, a family history screening tool to prevent common chronic diseases. Prev Chronic Dis. 2009; 6(1) A33

25. Caprara GV, Steca P, Gerbino M, et al. Looking for adolescents' well-being: self-efficacy beliefs as determinants of positive thinking and happiness. Epidemiol Psichiatr Soc. 2006; 15:30-43.

26. Gupta G, Kumar S. Mental health in relation to emotional intelligence and self efficacy among college students. Journal of the Indian Academy of Applied Psychology 2010; 36:61-7.

27. Tong Y, Song S. A Study on General Self-Efficacy and Subjective Well-Being of Low SES-College Students in a Chinese University. Coll Stud J 2004; 38:637.

28. Iannotti RJ, Schneider S, Nansel TR, et al. Self-efficacy, outcome expectations, and diabetes self-management in adolescents with type 1 diabetes. J Dev Behav Pediatr. 2006; 27:98-105.

29. Littlefield CH, Craven JL, Rodin GM, et al. Relationship of self-efficacy and binging to adherence to diabetes regimen among adolescents. Diabetes Care 1992; 15:90-4. 